and characteristic schizophrenic anomalies, present or past, have been manifest. The terms indicate that this is the best place to classify some other poorly defined varieties of schizophrenia." 18

Although some Soviet psychiatrists manifestly resist what they find to be abuses of their profession, ${ }^{1319}$ in Britain and the West there is a range of opinion among psychiatrists, from belief that their colleagues in the Soviet Union will knowingly incarcerate perfectly sane dissidents to belief that at least some Soviet psychiatrists genuinely think that some dissidents are suffering from a mental disorder. In the absence of independent information many will probably agree with Windholz's assessment that "No final conclusion about the extent of political motivation in psychiatric commitment cases in the Soviet Union can be made without a well documented analysis of contemporary Soviet commitment practices." 20

Two general aspects of this problem are, however, clear. Firstly, the ethical controversies aroused in all countries by the compulsory detention and treatment of people in psychiatric institutions are heightened when the Soviet Union is considered, because literary ${ }^{21}$ and historical ${ }^{20}$ parallels-as well as contemporary accounts $\mathrm{s}^{2-7} 10-1319$-suggest that the misuse of psychiatry there is deep rooted and long established; because of the cultural, political, legal, and social conditions in that country; because of the lack of knowledge about Soviet medical ${ }^{22}{ }^{23}$ and psychiatric practices, ${ }^{23-29}$ especially those regarding compulsory confinement in "special" as well as "ordinary" psychiatric hospitals ${ }^{23}$; and, particularly, because of the close relationship between psychiatry and the state in the Soviet Union. Secondly, the use of diagnoses such as sluggish schizophrenia exposes fundamental deficiencies in the reliable and valid definition and classification of psychiatric disorders. This is underlined by the fact that in 1983 the World Psychiatric Association published no fewer than 15 different diagnostic criteria for schizophrenia, including that used in the Soviet Union. Overall, the reliability, concordance, and prediction of outcome of such criteria are unsatisfactory, though a few "emerge as relatively effective." 30 Doctors and medical science can make remedial interventions in both these domains; firstly, by continuing to encourage international professional inquiry and enlightenment; and, secondly, by promoting the collaborative research that is still required. ${ }^{3132}$

GREG WILKINSON

Honorary Lecturer,

General Practice Research Unit,

Institute of Psychiatry,

London SE5 8AF

1 British Medical Association. The torture report: report of a working party of the British Medical Association investigating the involvement of doctors in torture. London: British Medical Association, 1986.

2 Amnesty International (British Section). Prisoners of conscience in the USSR: their treatment and conditions (Second ed). London: Quartermaine House, 1980.

3 Bloch S, Reddaway P. Russia's political hospitals: the abuse of psychiatry in the Soviet Union. London: Victor Gollancz, 1977.

London: Victor Gollancz, 1977.
4 Bloch S, Reddaway P. Soviet psychiatric abuse: the shadow over world psychiatry. London: Victor Gollancz, 1984.

5 International Association on the Political Use of Psychiatry. Soviet political psychiatry. The story of the opposition. London: International Association on the Political Use of Psychiatry, 1983.

6 International Association on the Political Use of Psychiatry. Information bulletin No 12 (English edition). London: International Association on the Political Use of Psychiatry, December 1985

7 Working Group on the Internment of Dissenters in Mental Hospitals. Political abuse of psychiatry. $A$ list of victims 30 November 1985. London: International Association on the Political Use of Psychiatry, 1985.

8 Wynn A. The Soviet Union and the World Psychiatric Association. Lancet 1983;i:406-8.

9 Mersky H, Shafran B. Political hazards in the diagnosis of "sluggish schizophrenia." $\mathrm{Br} f$ Psychiatry 1986;148:247-56.

10 Bukovsky V, Gluzman S. A manual on psychiatry for dissidents. Reprinted from Survey (London) Winter/Spring 1975, for distribution by the Working Group on the Internment of Dissenters in Mental Hospitals.

11 Working Group on the Internment of Dissenters in Mental Hospitals. The political abuse of psychiatry in the Soviet Union. London: Working Group on the Internment of Dissenters in psychiaty in the Soviet Unio.
12 Podrabinek A. Punitive medicine. Ann Arbour: Karoma Publishers, 1979.

13 Koryagin A. Unwilling patients. Lancet 1981 ; i:821-4.

14 Snezhnevsky AV. The symptomatology, clinical forms and nosology of schizophrenia. In Howells JG, ed. Modern perspectives in world psychiatry. London: Oliver and Boyd, 1968:425-47. Howelis JG, ed. Modern perspectives in world psychiatry. London: Oliver and Boyd, 1968:425-47.
World Health Organisation. Report of the international pilot study of schizophrenia. Vol 1. Geneva: World Health Organisation. Report of
World Health Organisation, 1973.

World Health Organisation, 1973 .
Berner P, Gabriel E, Katschnig H, et al. Diagnostic criteria for schizophrenic and affective psychoses. Washington: Distributed by American Psychiatric Press for the World Psychiatric Association, 1983.

17 Jablensky A. Epidemiology of schizophrenia: A European perspective. Schizophr Bull 1986;12: 52-73.

18 World Health Organisation. Mental disorders: glossany and guide to their classification in accordance with the Ninth Revision of the International Classification of Diseases. Geneva: World Health Organisation, 1978.

19 Working Group on the Internment of Dissenters in Mental Hospitals. Dr Semyon Gluzman: the imprisoned conscience of Soviet psychiatry. London: Working Group on the Internment of Dissenters in Mental Hospitals, 1977.

20 Windholz G. Psychiatric commitments of religious dissenters in Tsarist and Soviet Russia: two case studies. Psychiatry 1985;48:329-40

1 Chekhov AP. Ward 6. In: Lady with lapdog and other stories. Harmondsworth: Penguin, 1964.

Kaser M. Health care in the Soviet Union and Eastern Europe. London: Croom Helm, 1976.

23 Ryan M. The organisation of Soviet medical care. Oxford: Basil Blackwell and Martin Robertson, Ryan M.

24 Galach'yan AG. Soviet Union. In: Kiev A, ed. Psychiatry in the communist world. New York: Science House, 1968:29-50.

25 Brown BS, Kopin IJ, Kramer M, et al. The 1972 NIMH mission to assess schizophrenic research in the USSR. In: Brown BS, Torrey EF, eds. International collaboration in mental health. Rockville: National Institute of Mental Health, 1973:17-25.

26 Corson SA, Corson EO'L, eds. Psychiatry and psychology in the USSR. New York: Plenum Press, 1976.

27 Mombour W. Comparison between different systems of psychiatric education including some aspects on the ideology of different mental health systems. In: Alino JJL-I, Lenz G, eds. Training and education in psychiatry. Wien: Facultas Verlag, 1984:306-17.

28 Miller MA. The theory and practice of psychiatry in the Soviet Union. Psychiatry 1985;48:13-24. 9 Babayan E. The structure of psychiatry in the Soviet Union. (In collaboration with YuG Shashina.) New York: International Universities Press, 1985.

30 Brockington IF, Kendell RE, Leff JP. Definitions of schizophrenia: concordance and prediction of outcome. Psychol Med 1978;8:387-98.

of outcome. Psychol Med 1978;8:387-98. International Pilot Study of Schizophrenia. Psychol Med 1977;7:529-41.

32 World Health Organisation. Schizophrenia: an international follow-up study. Chichester: John Wiley, 1979

\section{A star treatment for digoxin overdose?}

The conventional management of intoxication with cardiac glycosides is unsatisfactory. Supportive measures and cardiac pacing are the mainstays as attempts to increase the elimination of glycosides have not been successful. The development of digoxin antibodies for measuring concentrations of this drug and the subsequent demonstration of their ability to abolish digoxin toxicity in animals ${ }^{1}$ were therefore potentially important advances.

The antibodies were first used in man in $1976,{ }^{2}$ but production problems have severely restricted supplies. ${ }^{3}$ However, Digibind (Wellcome Foundation Ltd) is now generally available in Britain, and Digitalis Antidote BM (Boeringher Mannheim $\mathrm{GmbH}$ ) has already been released in Europe. ${ }^{4}$ These digoxin specific antibodies are raised in sheep and cross react with digitoxin ${ }^{46}$ and lanatoside C. Giving intact immunoglobulins is unnecessary; digoxin specific Fab fragments obtained by cleaving whole antibodies are sufficient. These should distribute rapidly into a large volume as they have a small mass- 50000 daltons. They should also be less immunogenic than whole antibodies because antigenic determinants and complement binding sites are eliminated.

Assessing their efficacy in a controlled trial seems superfluous. Sixty three patients with severe poisoning - that is, with life threatening arrhythmias or hyperkalaemia, or bothwere given the Wellcome preparation intravenously over 15-30 minutes. They ranged in age from a few days to 85 years and included 28 who had taken massive overdoses. Fifty three of the 56 patients suitable for analysis recovered 
completely. ${ }^{5}$ In a trial of Digitalis Antidote BM 32 out of 34 patients were successfully treated. In neither series could deaths be attributed to failure to reverse digitalis toxicity.

In some cases the rate of reversal has been dramatic: gastrointestinal features disappeared almost immediately, and hyperkalaemia was corrected within 30-60 minutes of the end of the infusion. ${ }^{8}$ Some arrhythmias have been corrected equally quickly in some patients ${ }^{8}$ but more slowly (up to 13 hours; mean 3.2) in others. ${ }^{4}$ Even digitoxin induced thrombocytopenia was considerably improved within hours. ${ }^{6}$ Equally important, infusion of Fab fragments has been well tolerated: no immediate or delayed hypersensitivity reactions have been reported, and the few reported adverse effects were probably due to other factors. ${ }^{45}$

Doctors hesitate before awarding star status to any new treatment, but digoxin antibodies appear to come into that category, although they are expensive. For the foreseeable future, however, their use must be restricted to treating severe intoxication and continued careful monitoring for adverse effects will be mandatory. The poisons information services will advise.

\section{A T PROUDFoOT}

Director,

Scottish Poisons Information Bureau,

Roval Infirmary,

Edinburgh EH3 9YW

1 Schmidt DH, Butler VP. Reversal of digoxin toxicity with specific antibodies. $\mathcal{J}$ Clin Invest 1971:50:1738-44.

2 Smith TW, Haber E, Yeatman L, Butler VP. Reversal of advanced digoxin intoxication with Fab fragments of digoxin-specific antibodies. N Engl f Med 1976;294:797-800.

Smith TW. New advances in the assessment and treatment of digitalis toxicity. $f$ Clin Pharmacol 1985;25:522-8.

4 Smolarz A, Roesch E, Lenz E, Neubert $H$, Abshagen P. Digoxin specific antibody (Fab) fragments in 34 cases of severe digitalis intoxication. $\mathcal{F}$ Toxicol Clin Toxicol 1985;23:327-40.

W'enger TL, Butler VP, Haber E, Smith TW. Treatment of 63 severely digitalis-toxic patients with digoxin-specific antibody fragments. $f$ Am Coll Cardiol 1985;5(suppl A): 118-23A.

6 Hess T, Riesen W, Scholtysik G, Stucki P. Digitoxin intoxication with severe thrombocytopenia: reversal by digoxin-specific antibodies. Eur $\mathcal{f}$ Clin Invest 1983;13:159-63.

7 Hess T, Stucki P, Barandun S, Scholtysik G, Reisen W. Treatment of a case of lanatoside C intoxication with digoxin-specific $\mathrm{F}\left(\mathrm{ab}^{\prime}\right)_{2}$ antibody fragments. Am Heart $\mathrm{f}$ 1979;98:767-71.

8 Spiegel A, Marchlinski FE. Time course for reversal of digoxin toxicity with digoxin-specific antibody fragments. Am Heart f 1985;109:1397-9.

\section{Severe head injury: the first hour}

Only a few of the $1 \cdot 1$ million patients ${ }^{1}$ who present annually to casualty departments with head injuries arrive having been unconscious since the moment of injury. Many of these patients have other life threatening injuries ${ }^{2}$ and their prognosis may be poor, but their management in the first hour after injury is crucial. Unfortunately standards of care vary widely: some patients are correctly fully assessed and resuscitated, while others are put back in the ambulance after little more than a cursory examination and hurriedly transferred to a neurosurgical unit. Patients transferred too quickly may arrive in a worse condition than when they left the receiving hospital. ${ }^{3}$

Experience is the key to proper management, and inexperienced casualty officers tend to move patients too quickly. Where geography permits, patients with severe head injuries should be taken to large accident units and met at the door by senior anaesthetists and surgeons-as is the case with the Lewisham trauma team. ${ }^{+}$
How should these patients be managed initially? Little can be done about the impact damage to the brain, ${ }^{5}$ but secondary damage caused by hypoxia, airway obstruction, hypercapnia, and hypotension must be prevented. ${ }^{6}$ Only once this has been done can attention be allowed to turn towards reducing intracranial pressure raised by haematomas or cerebral oedema.

The first question is whether the patient is breathing properly? If not, the airway should be cleared and he may need to be intubated and ventilated immediately. The need to insert chest drains should also be considered. ${ }^{7}$ While this is being done, blood pressure should be checked and if low corrected immediately. Continuing blood loss should be sought and stopped. The head injury is virtually never responsible for low blood pressure except when there is massive scalp bleeding. ${ }^{8}$ This can be controlled by a few sutures to all layers of the scalp and head bandaging. The wounds can be tidied up later if necessary, when the patient is stable. If intra-abdominal or intrathoracic blood loss are suspected they should be dealt with before transfer. No patient should start an ambulance journey with unstable blood pressure.

Once the patient is breathing well (either spontaneously or on a ventilator) and blood pressure is near normal and stable, a thorough examination should be undertaken. Particular attention should be paid to the spine and major body cavities. Radiographs should be obtained of the skull, cervical spine, chest, and other areas of clinical suspicion. Limb fractures should be splinted, and antibiotics and tetanus toxoid given when indicated. Only at this stage is the patient fit for transfer, and he must be accompanied by an experienced anaesthetist, a nurse, high quality notes, and radiographs. Managing respiratory problems and hypotension in a moving ambulance is exceedingly difficult, and all tubes and drips should be well secured before the journey starts. Police assistance may be obtained for a smooth journey, but a tyre squealing ambulance trip with sirens blaring should not be necessary and is best avoided.

Is there a need for craniotomy at the receiving hospital?? Usually the answer is no. Most often these patients have suffered severe primary brain damage, and neurological deterioration is due either to rapid brain swelling ${ }^{5}$ or a rapidly accumulating subdural haematoma. ${ }^{10}$ Acute subdural haematomas are usually due to brain lacerations or torn venous sinuses, ${ }^{11}$ and thus the exploring surgeon must be able to perform a major craniotomy and stop bleeding. This can be a difficult task even for an experienced neurosurgeon in a neurosurgical theatre. A general surgical registrar may be able to remove an extradural haematoma with a drill, some bone nibblers, and a copy of Hamilton Bailey's Emergency Surgery, ${ }^{12}$ but a patient unconscious from impact who deteriorates neurologically within one hour will almost invariably not have an extradural haematoma. He is unlikely to benefit from emergency surgery by an inexperienced surgeon in less than perfect conditions.

The essence of managing this type of emergency is not to panic but rather to consider and correct all extracranial abnormalities. The aim should be to present the neurosurgeon with a damaged but well oxygenated and well perfused brain. This will give the patient the greatest chance of recovery.

Peter Richards

Neurosurgical Senior Registrar,

Charing Cross Hospital,

London W6 8RF 